\title{
USING THE LABOUR OF SPECIAL SQUADS IN THE STALINGRAD REGION IN 1942-1945
}

\author{
Sergey G. Sidorov \\ Volgograd State University, Volgograd, Russian Federation \\ Vladimir V. Shevchenko \\ Museum of History of the Old Sarepta, Volgograd, Russian Federation
}

\begin{abstract}
Special purpose camps for the NKVD of the USSR were established in 1941 to carry out a special inspection of former Red Army servicemen emerging from captivity or encirclement. In 1942 the labour of special squads started to be carried out at certain economic facilities of the country.

The article deals with the issues related to the use of special forces in the Stalingrad region during the Great Patriotic War. The case of the Stalingrad region is interesting due to the fact that it showcases the overall evolution of the system of special camps, beginning with the creation of the first camps on December 28, 1941 by the Order of the NKVD of the USSR, and till their liquidation, which began in 1945. The Kamyshinsky special camp, which provided the workforce fo railway construction, was one of the first special camps in which forced labour of the special squads was used. Later, camp no. 018, which provided the workforce for restoration of the destroyed enterprises, was established in the region. The camp's personnel worked mainly on the restoration of the Stalingrad Tractor Plant. The authors also study other regional objects on which special squads' labour was used, as well as their organization and effectiveness. It is noted that the labour of highly qualified special squads was in demand in various sectors of the economy. The variable composition of special camps located on the territory of the Stalingrad region made a significant contribution to the restoration of the city and its major plants. This was promoted by the increasing literacy of labour organization, and by the improvement of the material supply of special camps. Special attention is paid to the transfer of the special squads to the permanent staff of industry. V.V. Shevchenko compiled the necessary sources and wrote the paper. S.G. Sidorov revealed some relevant sources, pointed out the conception and accomplished academic editing of the paper.
\end{abstract}

Key words: special squads, restoration of Stalingrad, prisoners of war, forced labor, special camps.

Citation. Sidorov S.G., Shevchenko V.V. Using the Labour of Special Squads in the Stalingrad Region in 19421945. Vestnik Volgogradskogo gosudarstvennogo universiteta. Seriya 4, Istoriya. Regionovedenie. Mezhdunarodnye otnosheniya [Science Journal of Volgograd State University. History. Area Studies. International Relations], 2018, vol. 23, no. 1, pp. 105-115. (in Russian). DOI: https://doi.org/10.15688/jvolsu4.2018.1.10

УДК 94(470.45)"1942/1945":338.245

Дата поступления статьи: 12.09.2017

ББК 63.6(2Р-4Вог)622-2

Дата принятия статьи: 21.11.2017

\section{ИСПОЛЬЗОВАНИЕ ТРУДА СПЕЦКОНТИНГЕНТА В СТАЛИНГРАДСКОЙ ОБЛАСТИ В 1942-1945 ГОДАХ}

\section{Сергей Григорьевич Сидоров}

Волгоградский государственный университет, г. Волгоград, Российская Федерация

\section{Владимир Вячеславович Шевченко}

Музей-заповедник «Старая Сарепта», г. Волгоград, Российская Федерация

Аннотация. В статье рассматриваются вопросы, связанные с использованием труда спецконтингента на территории Сталинградской области в годы Великой Отечественной войны. Интерес к Сталинградской 
области обусловлен тем, что на ее примере можно проследить эволюцию системы спецлагерей практически на всем протяжении ее существования: начиная от создания первых лагерей по приказу НКВД СССР от 28 декабря 1941 г. и заканчивая их ликвидацией, начавшейся в 1945 году. Авторами рассматриваются объекты, на которых применялся труд спецконтингента на территории области, анализируется его организация и эффективность. Отдельное внимание уделяется вопросам передачи спецконтингента в постоянные кадры промышленности. В.В. Шевченко осуществлял сбор источников и написание текста статьи, С.Г. Сидоров проводил выявление отдельных источников, определял концепцию и научное редактирование статьи.

Ключевые слова: спецконтингент, восстановление Сталинграда, военнопленные, принудительный труд, спецлагеря.

Цитирование. Сидоров С. Г., Шевченко В. В. Использование труда спецконтингента в Сталинградской области в 1942-1945 годах // Вестник Волгоградского государственного университета. Серия 4, История. Регионоведение. Международные отношения. -2018. - Т. 23, № 1. - С. 105-115. - DOI: https://doi.org/10.15688/ jvolsu4.2018.1.10

Великая Отечественная война является одним из ключевых событий отечественной истории. Безусловно, в ее историографии, несмотря на наличие определенного общественного консенсуса в отношении значения события в целом, присутствует немало дискуссий, касающихся тех или иных отдельных аспектов. Одной из наиболее остродискуссионых проблем в историографии является судьба советских военнослужащих, освобожденных из фашистского плена. В ходе полемики на страницах журнала «Россия XXI век» между Г.Г. Вербицким и В.Н. Земсковым впервые был поднят вопрос об использовании труда и судьбе бывших военнопленных после прохождения спецпроверки.

В целом для авторов, занимающихся данной проблемой, характерно сосуществование прямо противоположных мнений. Так, в исследованиях Л.П. Белякова [1] и И.В. Кузнецова [13] отражаются наиболее распространенные стереотипы, касающиеся тотальных масштабов репрессий по отношению к бывшим военнослужащим, а также полного произвола органов, проводивших спецпроверку. В работах И.В. Пыхалова, напротив, фактически отрицаются какие-либо акты репрессий в отношении бывших военнопленных со стороны советского руководства [25].

Неудачи на фронтах в первые дни Великой Отечественной предопределили складывание у советского руководства однозначного негативного отношения к гражданам, оказавшимся в плену. 16 августа 1941 г. выходит знаменитый приказ № 270 «Об ответственности военнослужащих за сдачу в плен и оставление врагу оружия», предписывающий про- должать борьбу в любой ситуации любыми средствами. Сам факт попадания в плен означал невыполнение данного приказа и позволял зачислить всех оказавшихся в плену в разряд «изменников Родины».

Вместе с тем в ходе дальнейшего развития событий на фронтах стала явной несостоятельность проводимой репрессивной политики. Наиболее ярко порочность сложившейся практики проявилась во время битвы за Москву. Только на участке одного Можайского укрепрайона за три дня (с 16 по 18 октября), по данным органов госбезопасности, из окружения или плена вышло более 23 тысяч красноармейцев [32, с. 65].

Объявлять такую массу людей «врагами народа» было, по меньшей мере, расточительно, особенно в условиях военного времени. Вместе с тем обстановка не позволяла им безоговорочно доверять, поскольку некоторые военнопленные добровольно шли на сотрудничество с разведорганами противника. Например, уже в октябре 1941 г. НКВД располагал информацией об организованных на оккупированных территориях разведшколах противника, в которых проходили обучение курсанты, завербованные из числа советских военнопленных [32, с. 63].

Поиски путей наиболее эффективного решения обозначенной проблемы привели к тому, что оптимальным вариантом было признано создание института фильтрации. Для ее осуществления согласно решению ГКО № 1069сс от 27 декабря 1941 г. были созданы спецлагеря НКВД СССР и армейские сборно-пересыльные пункты [16, л. 29]. На следующий день, 28 декабря, увидел свет приказ 
Народного Комиссара внутренних дел СССР № 001735, предусматривавший прохождение в вышеупомянутых учреждениях специальной проверки всеми без исключения военнослужащими, вышедшими из плена или окружения.

Вопросы, связанные с организацией спецлагерей и содержанием в них спецконтингента, соблюдением режимных требований, были отнесены к компетенции управления НКВД СССР по делам о военнопленных и интернированных. Обеспечение спецлагерей помещениями, питанием, обмундированием и т. п. было возложено на Наркомат обороны [7, л. 119]. Освобожденные из плена граждане, направленные в спецлагеря, получали статус «спецконтингента» или «бывших военнослужащих».

Одним из первых по вышеупомянутому приказу должен был быть создан Ново-Аннинский спецлагерь в Сталинградской области. Он предназначался для обслуживания Южного фронта. Однако в Новоаннинском не удалось подобрать подходящие свободные помещения, пригодные для дислокации лагеря, поэтому было принято решение перенести его во Фролово. Но и здесь развертывание лагеря не удалось в полной мере: в частности, не были обеспечены необходимыми отдельными помещениями управление лагеря и его особый отдел. В результате сотрудникам последнего пришлось допрашивать часть проверяемых непосредственно в занимаемых ими бараках [26, л. 6].

Впрочем, как видно из документов, проблемы с размещением были не самыми серьезными в работе Фроловского спецлагеря. Без преувеличения катастрофической была и ситуация со снабжением лагеря. Так, начальник лагеря капитан госбезопасности П.М. Фокин в рапорте в УПВИ НКВД сообщал, что «на контингент 3000 человек имеется 1000 штук кроватей, нар нет, умывальников нет... <..> ...обмундирование получено только 200 комплектов старого, белья нет, постельной принадлежности нет, люди лежат на голых железных кроватях и на полу, тарелок 1 500, кружек 3000 , ложек приобрели сами 3000 штук» [26, л. 6]. Ответственность за сложившееся положение Фокин возлагал на военных, которые, по его мнению, ненадлежащим образом исполняли свои обязанности: «военный совет Сталинградского Военного округа... только сочувствует, выслушивая трудности лагеря, но реальной помощи не оказывает».

Данное явление нельзя назвать характерным исключительно для Сталинграда. С подобными проблемами в той или иной степени сталкивались начальники практически всех спецлагерей. Во многом оно было предопределено нечетким разграничением ответственности между УПВИ НКВД и Наркоматом обороны в вопросах снабжения лагерей.

Начальник тыла Красной Армии А.В. Хрулев в служебной записке по вопросам снабжения спецлагерей разделял ответственность военных округов за проблемы со снабжением с самими же спецлагерями: вторые ждут разного рода материальных благ, тогда как первые - «детальных заявок на предмет снабжения» (цит. по: [14, с. 54]). Выходом из сложившегося положения стала директива Главного управления тыла Красной Армии от 31 марта 1942 г. о разграничении полномочий снабжения спецлагерей между НКВД и НКО. Кроме того, следуя известной пословице, что «спасение утопающих - дело рук самих утопающих», НКВД дал спецлагерям установку на самообеспечение и самостоятельное снабжение. Для этого лагерям выделялись участки под подсобные хозяйства, из проверяемых формировались рыбацкие команды.

Таким образом, во всех спецлагерях, не исключая и Фроловский, должны были появиться подсобные хозяйства, использовавшие труд спецконтингента. Фактически же администрацией целого ряда лагерей данное указание выполнено не было. Вместе с тем, хотя использование труда переменного состава носило единичный характер, мы можем говорить о появлении экономической составляющей в функционале спецлагерей. Безусловно, речи о производственном характере данных учреждений в указанный период не идет.

К весне 1942 г. обострились проблемы в экономике страны, связанные, в частности, с элементарной нехваткой рабочих рук.

Это привело к новому явлению в деятельности спецлагерей - созданию лагерей сугубо производственного характера. Первым подобным лагерем стал развернутый согласно Приказу НКВД № 00567 от 20 марта 1942 г. Тульский спецлагерь НКВД на 5000 человек 
для использования спецконтингента на работах в Подмосковном угольном бассейне [22, л. 290]. Второй производственный лагерь был создан на территории Сталинградской области, становившейся ключевой в кампании лета 1942 года. Для строительства железной дороги Камышин - Иловля, являвшейся важным участком Волжской рокады и сыгравшей важную роль в снабжении войск в ходе Сталинградской битвы, приказом № 001465 от 11 июля 1942 г. за подписью Меркулова был создан Камышинский спецлагерь № 170 [21, л. 54]. По окончании работ, в сентябре 1942 г., Камышинский спецлагерь был расформирован.

Характерно, что принцип комплектования переменным составом Тульского и Камышинского спецлагерей в корне отличался от действовавшего ранее. В I квартале 1942 г. переменный состав большинства лагерей специального назначения НКВД СССР комплектовался из бывших бойцов РККА, направляемых в них со сборно-пересыльных армейских пунктов. Спецконтингент производственных лагерей стал формироваться путем перевода в них бывших военнослужащих из других аналогичных учреждений. При этом существовал строгий отбор по физическому состоянию людей. Кроме того, поскольку офицерский состав к труду не привлекался, в данные лагеря попадали, как правило, рядовые и младший начсостав.

Использование труда спецконтингента в 1942 г. не носило массовый характер. Из 27 созданных тогда спецлагерей лишь 4 являлись производственными [7, л. 119]. На это указывает и тот факт, что в данный период какая-либо нормативная база, регламентирующая труд бывших военнослужащих, отсутствовала. В ней еще не было острой необходимости.

В феврале 1943 г. на Сталинградской земле появился Урюпинский спецлагерь № 256. Трудовое использование контингентов данного лагеря не планировалось, он должен был выполнять приемно-распределительную функцию, ориентируясь на скорейший сбор всех бывших военнослужащих. При этом из Урюпинска все «подозрительные лица» должны были направляться для проверки в Рязанский спецлагерь, а «не внушающие подозрений»в военкоматы [2, л. 49].
Необходимость восстановления Сталинграда привела к созданию на территории города спецлагеря производственного характера. Уже в феврале 1943 г. на территории Сталинградского тракторного завода создается лагерное отделение численностью 300 человек, спецконтингент которого привлекался к работам по восстановлению предприятия. Однако рабочих рук остро не хватало, и в марте 1943 г. было принято решение об организации в составе управления лагеря № 108 для военнопленных лагеря № 0108 для бывших военнослужащих Красной Армии [23, л. 197-198], который первоначально был развернут на территории СТЗ.

Комплектовался лагерь из контингента, отобранного в Калачском и Урюпинском спецлагерях, а также переменного состава вышеупомянутого лаготделения. Общая численность бывших военнослужащих, содержащихся в лагере, изначально должна была достичь 3000 человек. Фактически же к июню в спецлагерь № 0108 поступило всего 1888 человек. Из них 331 человек был принят от лаготделения при СТ3, 500 человек - из спецлагеря НКВД № 258 (Калач), 1038 человек - из спецлагеря НКВД № 256 (Урюпинск) и 4 человека - из госпиталей. Кроме того, 15 человек поступило от комендатуры Сталинграда и УНКВД Сталинградской области [5, л. 2]. Стоит отметить, что организация учетной работы в лагере имела свои недостатки, из-за чего один и тот же человек попадал в две категории учета одновременно. Это приводило к имеющимся в документах разночтениям с количеством принятого спецконтингента. Впрочем, это было характерно не только для спецлагеря № 0108, но и для ряда других лагерей [4, л. 37].

Численность лагеря не была статичной он расширялся, что было обусловлено тем, что рабочие руки требовались не только на СТ3, но и на других объектах Сталинграда. По состоянию на начало июля 1943 г., до 20 \% переменного состава лагеря № 0108 было занято на работах на дополнительных участках вне основной зоны, располагавшейся на СТ3: стройучастке УНКВД «Сталинград II», участке при Сталгрэссе и в подсобном хозяйстве в хуторе Репьено [30, л. 46].

В конце июля 1943 г. создается лаготделение при заводе № 221 расчетной числен- 
ностью 1500 человек [20, л. 40]. Оно было автономно в вопросах использования труда и организации фильтрации спецконтингента, однако финансовое и материальное обеспечение получало через Управление лагеря № 108, а затем через финчасть лагеря № 0108.

К моменту развертывания лагеря № 0108 уже была создана соответствующая нормативная база: Приказом НКВД СССР № 00675 от 6 апреля 1943 г. был установлен порядок трудового использования, который распространялся и на военнопленных, и на спецконтингент.

Приказом предписывалось обеспечить правильную расстановку спецконтингента по рабочим местам, с тем, чтобы каждого из них использовать на производстве в полном соответствии с его физическим состоянием и профессиональными навыками. Однако перед тем, как быть допущенным к работе на объектах вне лагеря, спецконтингент (впрочем, как и военнопленные) должен был пройти карантин [19, л. 69-71].

Для бывших военнослужащих устанавливался 8-часовой рабочий день с четырьмя выходными в месяц. При этом ночной отдых должен был длиться не менее 8 часов без перерыва. Начальники же спецлагерей должны были таким образом осуществлять расстановку контингента на работы, чтобы не было необходимости в проведении допросов в ночное время [19, л. 69-71]. Вместе с тем порядок трудового использования спецконтингента на местах имел свои особенности. Определялись они спецификой региона и назначения лагеря, поскольку частные случаи порядка трудового использования регламентировались внутренним распорядком лагеря, приказами НКВД СССР и директивами Управления по делам военнопленных и интернированных НКВД СССР.

Так, например, зимой 1943/44 гг. в Сталинграде из-за отсутствия в лагере достаточного количества теплого обмундирования при температуре ниже $-15^{\circ} \mathrm{C}$ рабочий день должен был сокращаться до 6 часов, а при температуре воздуха ниже $-25{ }^{\circ} \mathrm{C}$ выводить спецконтингент на работы вообще запрещалось $[33$, с. 100]. В летнее время для переменного состава спецлагеря № 0108 рабочий день, напротив, был увеличен и составлял 10 часов. Рабочий же день, к примеру, вольнонаемных работников СТЗ в этот период составлял 12 часов. Меньшая продолжительность рабочего дня спецконтингента объясняется в данном случае вышупомянутой необходимостью проведения тех или иных оперативных мероприятий, незатрагивая вместе с тем время отдыха.

К трудовому использованию, как уже отмечалось, должен был привлекаться только рядовой и сержантский состав. Вместе с тем в Сталинграде отмечались отдельные факты привлечения к работам офицерского состава, имевшего гражданскую специальность, необходимую на том или ином участке работ. Безусловно, что подобные отступления от принятых норм не приветствовались УПВИ НКВД, хотя и строгих взысканий на руководителей спецлагерей, допускавших подобные нарушения, не налагалось [18, л.16 об.].

Тот факт, что с началом применения труда спецконтингента в экономике гражданская специальность становится первой статьей учета в лагере, говорит о том, что ей придавалось большее значение, чем военной. Объясняется это тем, что она была ключевой при определении сферы наиболее эффективного применения труда каждого конкретного бывшего военнослужащего.

Руководству спецлагерей предписывалось обеспечить правильную расстановку спецконтингента [19, л. 69-71]. Например, в спецлагере № 0108 шоферы, трактористы и механики, которых из-за войны не хватало в хозяйстве региона, работали, как правило, исключительно по своей специальности.

Бывшие военнослужащие, заканчивающие прохождение карантина либо имеющие квалификацию повара, портного, сапожника и т. д., привлекались главным образом к внутрилагерным работам [10, л. 3]. В качестве конкретного примера можно привести портного Акимцева, который из-за большой загруженности в лагере не выводился на основные производственные работы, а его спецпроверка явно затягивалась [12, л. 203].

Однако профессию, востребованную на производственном объекте или в спецлагере, имели отнюдь не все проходящие в нем проверку бывшие военнослужащие. Как правило, в таком случае они зачислялись в разнорабочие. При этом доля данной категории переменного состава была довольно высока: по 
состоянию на апрель 1945 г. в лагере № 0108 из 2891 человека к разнорабочим было отнесено 1449 человек, что составляет $50 \%$ списочного состава, хотя по социальному положению относились к рабочим и служащим (а следовательно, имели гражданские специальности) 2059 человек [29, л. 58-59]. Такие военнослужащие зачастую осваивали новую специальность непосредственно в процессе работы на промышленных предприятиях и стройках. Поскольку срок пребывания в лагере не превышал три-четыре месяца, то и новые профессии были, как правило, из числа не требующих длительной подготовки: слесари, каменщики и т. д.

Вместе с тем работа по специальности допускалась лишь тогда, когда такие специалисты требовались на предприятиях, где использовался спецконтингент. Поэтому квалифицированным работникам невостребованных на производстве профессий чаще всего приходилось трудиться в качестве разнорабочих, что вело к снижению эффективность труда в целом. Кроме того, использование редких специалистов как простых неквалифицированных разнорабочих вместо их основной специальности значительно тормозило восстановление определенных отраслей экономики страны. По этой причине отдельные специалисты, например, сотрудники рыбной отрасли, передавались на соответствующие предприятия специальными директивами, независимо от того, закончена их проверка или нет [27, л. 41]. В таких случаях спецпроверку они проходили по месту работы. В подобном же положении оказались, например, ветеринары [33, с. 103]. В начале 1945 г. выходит директива №768/8, согласно которой все лица, имеющие медицинское образование, могли использоваться в спецлагерях только в соответствующих должностях; при отсутствии же вакантной должности в лагере - передаваться в систему здравоохранения [3, л. 117].

Согласно Приказу НКВД № 00675 спецконтингент на производственных объектах должен был изолироваться от вольнонаемных рабочих $[19$, л. 70$]$. Однако реальная обстановка, конечно, вносила определенные коррективы, обусловленные фактической потребностью в рабочей силе на том или ином участке работы. Например, в спецлагере № 0108 некоторые бывшие военнослужащие работали в бригадах вместе с рабочими заводов [17, л. 103]. Кроме того, с сентября 1944 г. вместе со спецконтингентом в стройотделе НКВД работало 200 немецких военнопленных, что также нормативными документами запрещалось [9, л. 66]. Несмотря на ряд предписаний о недопустимости подобных нарушений, данное явление было практически повсеместным. Подтверждением тому служат предписания начальникам других спецлагерей, направленные в лагерь № 0108 в качестве предупреждения. Поскольку невыход на производство спецконтингента вел к тяжелым последствиям, то зачастую нарушался и порядок конвоирования.

В Сталинграде особенно были востребованы профессиональные навыки монтажников и токарей из числа бывших военнослужащих. Представители этих профессий, например, на СТ3, работали группами по 2-3 человека отдельно от остального переменного состава лагеря. Столь малочисленные группы, как правило, не конвоировались и не изолировались от работников предприятия. Более того, квалификация отдельных бывших военнослужащих позволяла им фактически руководить вольнонаемными сотрудниками на отдельных участках работ [8, л. 54-55].

К началу 1944 г. на работы по восстановлению СТЗ спецлагерем № 0108 выводилось около 2,5 тыс. человек. Что касается завода № 221, то здесь на работы выводилось в среднем 1,2 тыс. человек [8, л. 54-55]. Говоря о показателях эффективности, отметим, что средняя норма выработки переменного состава лаготделения несколько уступала аналогичному показателю на СТЗ. Если данный показатель на СТЗ в 1944 г. составлял $121 \%$ [28, с. 97], то на заводе № 221 $114 \%$. Объясняется это тем, что, как видно из документов, наиболее квалифицированный спецконтингент оставался в основной зоне лагеря, обеспечивающей рабочей силой СТ3. Кроме того, администрация завода № 221 допускала гораздо больше нарушений при обеспечении труда спецконтингента, снижая тем самым его эффективность [28, с. 93].

Кроме того, из-за острого «кадрового голода» в народном хозяйстве Сталинградской области в 1944 г. спецконтингент привлек- 
ли к работам по обеспечению вывоза хлеба из районов, задействовав при этом практически всех механиков и водителей, содержавшихся на тот момент в лагере. Кроме людей, был частично задействован и автотранспорт лагеря. Ввиду того, что задействованный спецконтингент проявил себя на данных работах весьма достойно, зачастую превосходя по эффективности труд гражданских лиц, начальник лагеря № 0108 ходатайствовал о передаче части бывших военнослужащих в постоянные кадры Союззаготтранса [15, л. 144].

Проведенный анализ позволяет говорить о том, что эффективность организации труда спецконтингента в Сталинграде постоянно возрастала. Так, доля бывших военнослужащих, выполнявших производственные нормы, в Сталинграде в 1943 г. составляла 48,6 \% (в среднем по стране - 48,9 \%), а в 1944 г. этот показатель достиг уже $51 \%$ (по стране $-49,1 \%)[33$, с. 107].

Оценивая вышеприведенные показатели, необходимо иметь в виду, что нормы выработки, поставленные перед спецконтингентом, были аналогичны нормам выработки вольнонаемных рабочих. При этом рабочий день переменного состава спецлагеря, как говорилось выше, составлял 10 часов, в то время как работники предприятий трудились по 12 часов. Хотя отклонения от указанной продолжительности рабочего дня, безусловно, были, однако массовыми их назвать достаточно сложно. В противном случае это создавало бы препятствия для проведения спецпроверки.

Таким образом, вышесказанное позволяет нам утверждать, что бо́льшая часть спецконтингента в Сталинграде работала с высокой отдачей, и его вклад в восстановление города был весьма значителен.

Как уже упоминалось, срок проверки в спецлагерях был ограничен 3-4 месяцами, после чего военнослужащие, успешно прошедшие проверку, направлялись к новому месту службы. Если изначально успешно прошедший проверку спецконтингент практически полностью передавался военкоматам, то позднее вместо действующей армии бывшие военнослужащие начинают отправляться в промышленность вне зависимости от их желания.

В Сталинграде передача прошедших проверку бывших военнослужащих в постоянные кадры промышленности началась с лаготделения при заводе № 221 в феврале 1944 года. Переменный состав данного отделения был полностью передан в кадры завода к июлю, после чего лаготделение было перепрофилировано для содержания военнопленных [28, с. 98].

Массовая передача спецконтингента, трудившегося на СТ3, в кадры промышленности началась несколько позднее, в IV квартале 1944 года. При этом в постоянные кадры промышленности передавалось до $100 \%$ проверенного рядового и сержантского состава. Поскольку восстановление разрушенного города требовало большого количества строителей, то спецконтингент передавался в основном в кадры строительного треста Сталинградского тракторостроя, а не в кадры самого предприятия [11, л. 4].

В кадры СТ3 попадали только бывшие военнослужащие, прошедшие тщательный отбор исходя из имевшейся у них квалификации. Например, в одной из телефонограмм УПВИ НКВД СССР напрямую предписывается отобрать 75 наиболее квалифицированных человек спецконтингента для последующей его передачи в постоянные кадры СТ3 [31, л. 10].

Кроме основных предприятий промышленности, бывший спецконтингент передавался и на другие гражданские объекты, на которых существовала острая нехватка рабочих рук. В качестве примера можно привести передачу шоферов Союззаготтрансу. Помимо этого, в Сталинграде бывшие военнослужащие направлялись в организации, занятые в жилищном строительстве. Не оставались в стороне и другие жизненно важные сферы жизни региона - например, пожарная охрана, в которую после окончания проверки были направлены на службу 388 человек [6, л. 59-66].

Основной состав спецконтингента Бекетовского лагеря № 0108 был передан в постоянные кадры в начале 1945 г., после чего Приказом НКВД СССР № 0058 от 3 февраля лагерь был расформирован [24, л. 381]. 32 человека, не прошедшие проверку, были переданы лагерному отделению при УНКВД по Сталинградской области [24, л. 381].

Для завершения проверки оставшегося спецконтингента и окончания строительства дома УНКВД по Сталинградской области 
НКВД СССР приказало организовать лаготделение при Стройотделе УНКВД по Сталинградской области с лимитом в 1000 человек [24, л. 381].

Таким образом, переменный состав спецлагерей, располагавшихся на территории Сталинградской области, внес заметный вклад в восстановление города и его основных заводов. Этому немало способствовала как возрастающая грамотность организации труда, так и улучшение материального снабжения спецлагерей. С распространением практики передачи проверенного спецконтингента в постоянные кадры промышленности проверочно-фильтрационные лагеря сыграли роль учреждений, организовавших трудовые мобилизацию и миграцию в соответствии с интересами страны в целом. Промышленность Сталинграда, получившая от спецлагеря № 0108 более 3000 не только разнорабочих, но и квалифицированных специалистов, не стала исключением.

\section{СПИСОК ЛИТЕРАТУРЫ}

1. Беляков, Л. П. Горькая судьба репатриированных военнопленных / Л. П. Беляков // Репрессированные геологи. - М. ; СПб. : ВСЕГЕИ, 1999. C. $419-422$.

2. Директива НКВД СССР № 001268 от 10 февраля 1943 г. // РГВА. - Ф. 1/п. - Оп. 9а. - Д. 8.

3. Директива НКВД СССР №768/8 от 14 января 1943 г. // ГАРФ. - Ф. 9408. - Оп. 1. - Д.16.

4. Директива УПВИ НКВД СССР №28/2/20353 от 7 августа 1943 г. // ГАВО. - Ф. 1128. - Оп. 1.-Д.1.

5. Доклад начальника спецлагеря № 0108 о состоянии и работе лагеря за второй квартал 1943 г. // ГАВО. - Ф. 1128. - Оп. 1. - Д. 17. - Л. 1-6.

6. Доклад начальника спецлагеря № 0108 о работе за четвертый квартал 1944 г. // ГАВО. Ф. 1128. - Оп. 1. - Д. 17.

7. Доклад о работе управления НКВД СССР по делам о военнопленных и интернированных по лагерям специального назначения за время Великой Отечественной войны // РГВА. - Ф. 1/п. Оп. 23а. - Д. 2. - Л. 118-141.

8. Докладная записка начальника спецлагеря № 0108 заместителю Наркома НКВД СССР т. Чернышеву о работе по состоянию на 1 августа 1944 г. // ГАВО. -Ф. 1128. - Оп. 1. - Д. 51.

9. Донесение начальника спецлагеря № 0108 в отдел спецлагерей НКВД СССР о совместной работе на объектах стройотдела УНКВД по Сталинг- радской области спецконтингента с немецкими военнопленными // ГАВО. - Ф. 1128. - Оп. 1. - Д. 51.

10. Донесение начальника спецлагеря № 0108 в Управление НКВД СССР по делам о военнопленных и интернированных о трудовом использовании спецконтингента за январь 1944 г. // ГАВО. Ф. 1128. - Оп. 1. - Д. 55.

11. Донесение начальника спецлагеря № 0108 начальнику управления НКВД СССР по делам о военнопленных и интернированных т. Петрову о выделении спецконтингента на строительство УНКВД // ГАВО. - Ф. 1128. - Оп. 1. - Д. 55.

12. Заявление Акимцева Н. М., содержащегося в проверочно-фильтрационном лагере № 0108, начальнику ГУЛАГа НКВД СССР с просьбой об отправке на фронт // ГАВО. - Ф. 1128. - Оп. 1. - Д. 18.

13. Кузнецов, И. В. Война после войны/И. В. Кузнецов // Абажур. - 2002. -№ 16-18. - С. 22-27.

14. Латышев, А. В. Система проверки военнослужащих Красной Армии, вернувшихся из плена или окружения : дис. ... канд. ист. наук / Латышев Артем Валерьевич. - М., 2016. - 253 с.

15. Обращение начальника проверочно-фильтрационного лагеря в отдел спецлагерей НКВД СССР с просьбой дать распоряжение о передаче в постоянные кадры Сталинградский «Союззаготтранс» 20 шоферов // ГАВО. - Ф. 1128. - Оп. 1. - Д. 55.

16. Постановление Государственного комитета обороны от 27 декабря 1941 г. № 1069сc // ГАРФ. Ф. 9408. - Оп. 1. - Д. 53.

17. Предписание начальника Управления НКВД СССР по делам о военнопленных и интернированных руководству спецлагеря № 0108 об изоляции спецконтингента от вольнонаемных рабочих // ГАВО. - Ф. 1128. - Оп. 1. - Д. 5.

18. Предписание начальника Управления НКВД СССР по делам о военнопленных и интернированных руководству спецлагеря № 0108 «О ликвидации нарушений при использовании спецконтингента на восстановительных работах» // ГАВО. Ф. 1128. - Оп. 1. - Д. 7.

19. Приказ НКВД СССР № 00675 от 6 апреля 1943 года с объявлением типового договора управления НКВД СССР по делам о военнопленных и интернированных, директивы о порядке трудового использования военнопленных, интернированных и спецконтингентов и табеля срочных донесений по трудовому использованию // ГАВО. - Ф. 1128. Оп. 1. -Д. 40.

20. Приказ НКВД СССР № 001308 «Об организации лаготделения в составе Бекетовского спецлагеря № 0108» // ГАВО. - Ф. 1128. - Оп. 1. - Д. 40.

21. Приказ НКВД СССР № 001465 от 11 июля 1942 г. // ГАРФ. - Ф. 9401. - Оп. 1. - Д. 641.

22. Приказ НКВД СССР № 00567 от 20 марта 1942 г. // ГАРФ. - Ф. 9401. - Оп. 1. - Д. 636. 
23. Приказ НКВД СССР № 00512 от 23 марта 1943 г. // ГАРФ. - Ф. 9401. - Оп.1а. - Д. 133.

24. Приказ НКВД СССР № 0058 от 3 февраля 1945 г. «О расформровании спецлагеря № 0108» // ГАРФ. - Ф. 9401. - Оп. 1а. - Д. 174.

25. Пыхалов, И. Великая Оболганная война / И. Пыхалов. - М. : Яуза : Эксмо, 2005. - 480 с.

26. Рапорт начальника Фроловского лагеря специального назначения в УПВИ НКВД о положении со снабжением лагеря // РГВА. - Ф. 1/п. Оп. 7а. - Д. 1.

27. Распоряжение № 28/К/16783 начальника Управления НКВД СССР по делам военнопленных и интернированных о направлении в отдел кадров УПравления специалистов, занятых до войны в рыбной промышленности // ГАВО. - Ф. 1128. - Оп. 1. - Д. 1.

28. Савина, Т. А. Документы управления проверочно-фильтрационного лагерного отделения № 0108 об использовании на восстановлении г. Сталинграда спецконтингента в 1943-1945 гг. / Т. А. Савина // Окончание войны в Сталинграде и Кёльне : материалы науч. конф. - Волгоград : Изд-во ВолГУ, 1997. - С. 94-100.

29. Сведения о спецконтингенте спецлагеря НКВД № 0108 по состоянию на 5 апреля 1944 г. // ГАВО. - Ф. 1128. - Оп. 1. - Д. 18.

30. Справка о дислокации спецлагеря № 0108 и его участков по состоянию на 1 июля 1943 г. // ГАВО. -Ф. 1128. - Оп. 1. - Д. 4.

31. Телефонограмма Управления НКВД СССР по делам о военнопленных и интернированных начальнику спецлагеря № 0108 о немедленной передаче спецконтингента в постоянные кадры СТЗ // ГАВО. - Ф. 1128. - Оп. 1. - Д. 8.

32. Чертопруд С. НКВД-НКГБв годы Великой Отечественной Войны. - М. : Яуза : Эксмо, 2005. - 416 с.

33. Шевченко, В.В.Деятельность лагерей специального назначения НКВД СССР в 1941-1946 годах : дис. ... канд. ист. наук : 07.00.02 / Шевченко Владимир Вячеславович. - Волгоград, 2010. - 223 с.

\section{REFERENCES}

1. Belyakov L.P. Gorkaya sudba repatriirovannykh voennoplennykh [The Bitter Fate of Repatriated Prisoners of War]. Repressirovannye geologi [Repressed Geologists]. Moscow; Saint Petersburg, VSEGEI Publ., 1999, pp. 419-422.

2. Direktiva NKVD SSSR № 001268 ot 10 fevralya 1943 g. [Directive of the USSR NKVD no. 001268 of February 10, 1943]. Rossiyskiy gosudarstvennyy voennyy arkhiv [Russian State Military Archive], F. 1/p, Op. 9a, D. 8.

3. Direktiva NKVD SSSR №768/8 ot 14 yanvarya $1943 \mathrm{~g}$. [Directive of the USSR NKVD no. 768/8 of
January 14, 1943]. Gosudarstvennyy arkhiv Rossiyskoy Federatsii [State Archive of the Russian Federation], F. 9408, Op. 1, D. 16.

4. Direktiva UPVI NKVD SSSR №28/2/20353 ot 7 avgusta 1943 goda [Directive of the UPVI NKVD of the USSR no. 28/2/20353 of August 7, 1943]. Gosudarstvennyy arkhiv Volgogradskoy oblasti [State Archive of the Volgograd Region], F. 1128, Op. 1, D. 1.

5. Doklad nachalnika spetslagerya № 0108 o sostoyanii i rabote lagerya za vtoroy kvartal $1943 \mathrm{~g}$. [Report of the Chief of Special Camp no. 0108 on the Condition and Work of the Camp for the Second Quarter of 1943]. Gosudarstvennyy arkhiv Volgogradskoy oblasti [State Archive of the Volgograd Region], F. 1128, Op. 1, D. 17, L. 1-6.

6. Doklad nachalnika spetslagerya № 0108 o rabote za chetvertyy kvartal $1944 \mathrm{~g}$. [Report of the Chief of Special Camp no. 0108 on the Work for the Fourth Quarter of 1944]. Gosudarstvennyy arkhiv Volgogradskoy oblasti [State Archive of the Volgograd Region], F. 1128, Op. 1, D. 17.

7. Doklad o rabote upravleniya NKVD SSSR po delam o voennoplennykh i internirovannykh po lageryam spetsialnogo naznacheniya za vremya Velikoy Otechestvennoy voyny [Report on the Work of the NKVD of the USSR on Prisoners of War and the Internees in Special Purpose Camps During the Great Patriotic War]. Rossiyskiy gosudarstvennyy voennyy arkhiv [Russian State Military Archive], F. 1/p, Op. 23a, D. 2, L. 118-141.

8. Dokladnaya zapiska nachalnika spetslagerya № 0108 zamestitelyu Narkoma NKVD SSSR t. Chernyshevu o rabote po sostoyaniyu na 1 avgusta 1944 g. [Memorandum of the Head of Special Camp no. 0108 to Comrade Chernyshev, Deputy People's Commissar of the NKVD of the USSR, on the Work of August 1, 1944]. Gosudarstvennyy arkhiv Volgogradskoy oblasti [State Archive of the Volgograd Region], F. 1128, Op. 1, D. 51.

9. Donesenie nachalnika spetslagerya № $0108 \mathrm{v}$ otdel spetslagerey NKVD SSSR o sovmestnoy rabote na obyektakh stroyotdela UNKVD po Stalingradskoy oblasti spetskontingenta s nemetskimi voennoplennymi [Report of the Head of Special Camp no. 0108 to the Department of Special Camps of the NKVD of the USSR on Joint Work at the Objects of the Construction Department of the NKVD in the Stalingrad Region of a Special Contingent with German Prisoners of War]. Gosudarstvennyy arkhiv Volgogradskoy oblasti [State Archive of the Volgograd Region], F. 1128, Op. 1, D. 51.

10. Donesenie nachalnika spetslagerya № 0108 v Upravlenie NKVD SSSR po delam o voennoplennykh i internirovannykh o trudovom ispolzovanii spetskontingenta za yanvar $1944 \mathrm{~g}$. [Report of the Head of Special Camp no. 0108 to the NKVD of the USSR on Prisoners of War and the 
Internees about the Employment of Special Squads for January 1944]. Gosudarstvennyy arkhiv Volgogradskoy oblasti [State Archive of the Volgograd Region], F. 1128, Op. 1, D. 55.

11. Donesenie nachalnika spetslagerya № 0108 nachalniku upravleniya NKVD SSSR po delam o voennoplennykh i internirovannykh t. Petrovu o vydelenii spetskontingenta na stroitelstvo UNKVD [Report of the Chief of Special Camp no. 0108 to the Chief of the NKVD of the USSR on Prisoners of War and the Internees, to Comrade Petrov on the Allocation of Special Squads for the Construction of the NKVD]. Gosudarstvennyy arkhiv Volgogradskoy oblasti [State Archive of the Volgograd Region], F. 1128, Op. 1, D. 55.

12. Zayavlenie Akimtseva N. M., soderzhashchegosya v proverochno-filtratsionnom lagere № 0108, nachalniku GULAGa NKVD SSSR s prosboy ob otpravke na front [Statement of N. M. Akimtsev from the Check-and-Filtration Camp no. 0108 to the Head of the Gulag of the NKVD of the USSR with a Request to be Sent to the Frontline]. Gosudarstvennyy arkhiv Volgogradskoy oblasti [State Archive of the Volgograd Region], F. 1128, Op. 1, D. 18.

13. Kuznetsov I.V. Voyna posle voyny [War after the War]. Abazhur, 2002, no. 16-18, pp. 22-27.

14. Latyshev A.V. Sistema proverki voennosluzhashchikh Krasnoy Armii, vernuvshikhsya iz plena ili okruzheniya: dis. ... kand. ist. nauk [The System of Checking the Servicemen of the Red Army, Who Returned from Captivity or Encirclement. Cand. hist. sci. diss.]. Moscow, 2016. 253 p.

15. Obrashchenie nachalnika proverochnofiltratsionnogo lagerya $\mathrm{v}$ otdel spetslagerey NKVD SSSR s prosboy dat rasporyazhenie o peredache $\mathrm{v}$ postoyannye kadry Stalingradskiy «Soyuzzagottrans» 20 shoferov [Appeal of the Chief of the Check-andFiltration Camp to the Department of Special Camps of the USSR NKVD with a Request to Give the Order to Transfer 20 Drivers to the Permanent Staff of the Stalingrad "Soyuzagottrans"]. Gosudarstvennyy arkhiv Volgogradskoy oblasti [State Archive of the Volgograd Region], F. 1128, Op. 1, D. 55.

16. Postanovlenie Gosudarstvennogo komiteta oborony ot 27 dekabrya 1941 g. № 1069ss [Decree of the State Defense Committee of December 27, 1941 no. 1069ss]. Gosudarstvennyy arkhiv Volgogradskoy oblasti [State Archive of the Volgograd Region], F. 9408, Op. 1, D. 53.

17. Predpisanie nachalnika Upravleniya NKVD SSSR po delam o voennoplennykh i internirovannykh rukovodstvu spetslagerya № 0108 ob izolyatsii spetskontingenta ot volnonaemnykh rabochikh [Instruction of the Head of the NKVD of the USSR on Cases of War Prisoners and Internees of the Leadership of Special Camp no. 0108 on Isolating the
Special Squads from Civilian Workers]. Gosudarstvennyy arkhiv Volgogradskoy oblasti [State Archive of the Volgograd Region], F. 1128, Op. 1, D. 5.

18. Predpisanie nachalnika Upravleniya NKVD SSSR po delam o voennoplennykh i internirovannykh rukovodstvu spetslagerya № 0108 «O likvidatsii narusheniy pri ispolzovanii spetskon tingenta na vosstanovitelnykh rabotakh» [Instruction of the Head of the NKVD of the USSR on the Prisoners of War and Internees of the Leadership of Special Camp no. 0108 "On Elimination of Violations in the Use of Special Squads for Restoration Works"]. Gosudarstvennyy arkhiv Volgogradskoy oblasti [State Archive of the Volgograd Region], F. 1128, Op. 1, D. 7.

19. Prikaz NKVD SSSR № 00675 ot 6 aprelya 1943 goda s obyyavleniem tipovogo dogovora upravleniya NKVD SSSR po delam o voennoplennykh i internirovannykh, direktivy o poryadke trudovogo ispolzovaniya voennoplennykh, internirovannykh i spetskontingentov i tabelya srochnykh doneseniy po trudovomu ispolzovaniyu [Order of the USSR NKVD no. 00675 of April 6, 1943, Announcing a Standard Contract for the Administration of the NKVD of the USSR for Prisoners of War and Internees, a Directive on the Procedure for the Employment of Prisoners of War, Internees and Special Squads, and a Report Card for Urgent Employment Reports]. Gosudarstvennyy arkhiv Volgogradskoy oblasti [State Archive of the Volgograd Region], F. 1128, Op. 1, D. 40.

20. Prikaz NKVD SSSR № 001308 «Ob organizatsii lagotdeleniya $\mathrm{v}$ sostave Beketovskogo spetslagerya № 0108» [Order of the USSR NKVD no. 001308 “'On the Organization of Camp Branch within the Beketovsky Special Camp no. 0108"]. Gosudarstvennyy arkhiv Volgogradskoy oblasti [State Archive of the Volgograd Region], F. 1128, Op. 1, D. 40.

21. Prikaz NKVD SSSR № 001465 ot 11 iyulya 1942 g. [Order of the USSR NKVD no. 001465 of July 11, 1942]. Gosudarstvennyy arkhiv Rossiyskoy Federatsii [State Archive of the Russian Federation], F. 9401, Op. 1, D. 641.

22. PrikazNKVDSSSR№ 00567 ot 20 marta 1942 g. [Order of the USSR NKVD no. 00567 of March 20, 1942]. Gosudarstvennyy arkhiv Rossiyskoy Federatsii [State Archive of the Russian Federation], F. 9401, Op. 1, D. 636.

23. Prikaz NKVD SSSR № 00512 ot 23 marta $1943 \mathrm{~g}$. [Order of the USSR NKVD no. 00512 of March 23, 1943]. Gosudarstvennyy arkhiv Rossiyskoy Federatsii [State Archive of the Russian Federation], F. 9401, Op. 1a, D. 133.

24. Prikaz NKVD SSSR № 0058 ot 3 fevralya 1945 g. «O rasformrovanii spetslagerya № 0108» [Order of the USSR NKVD no. 0058 of February 3, 1945 “On the Dissolution of the Special Camp no. 0108]. Gosudarstvennyy arkhiv Rossiyskoy Federatsii [State 
Archive of the Russian Federation], F. 9401, Op. 1a, D. 174.

25. Pykhalov I. Velikaya Obolgannaya voyna [The Great Maligned War]. Moscow, Yauza Publ.; Eksmo Publ., 2005. 480 p.

26. Raport nachalnika Frolovskogo lagerya spetsialnogo naznacheniya v UPVI NKVD o polozhenii so snabzheniem lagerya [Report of the Chief of the Frolovsky Special Purpose Camp in the NKVD UPV on Camp Provision]. Rossiyskiy gosudarstvennyy voennyy arkhiv [Russian State Military Archive], F. 1/p, Op. 7a, D. 1.

27. Rasporyazhenie № 28/K/16783 nachalnika Upravleniya NKVD SSSR po delam voennoplennykh i internirovannykh o napravlenii $\mathrm{v}$ otdel kadrov Upravleniya spetsialistov, zanyatykh do voyny $\mathrm{v}$ rybnoy promyshlennosti [Order no. 28/K/16783 of the Chief of the NKVD Department of the USSR on Prisoners of War and Internees about Sending the Specialists Engaged in the Fishing Industry before the War to the Personnel Department]. Gosudarstvennyy arkhiv Volgogradskoy oblasti [State Archive of the Volgograd Region], F. 1128, Op. 1, D. 1.

28. Savina T.A. Dokumenty upravleniya proverochno-filtratsionnogo lagernogo otdeleniya № 0108 ob ispolzovanii na vosstanovlenii g. Stalingrada spetskontingenta v 1943-1945 gg. [Control Documents of Check-and-Filtration Camp Department no. 0108 on the Use of Special Squads in the Restoration of Stalingrad in 1943-1945]. Okonchanie voyny $v$ Stalingrade $i$ Kelne: materialy nauch. konf. [End of the War in Stalingrad and Cologne. Proceedings of the Academic Conference]. Volgograd Izd-vo VolGU, 1997, pp. 94-100.
29. Svedeniya o spetskontingente spetslagerya NKVD № 0108 po sostoyaniyu na 5 aprelya 1944 g. [Information about the Special Squads of the Special Camp of the NKVD no. 0108 as of April 5, 1944]. Gosudarstvennyy arkhiv Volgogradskoy oblasti [State Archive of the Volgograd Region], F. 1128, Op. 1, D. 18.

30. Spravka o dislokatsii spetslagerya № $0108 \mathrm{i}$ ego uchastkov po sostoyaniyu na 1 iyulya $1943 \mathrm{~g}$. [Reference about the Deployment of Special Camp no. 0108 and Its Sections as of July 1, 1943]. Gosudarstvennyy arkhiv Volgogradskoy oblasti [State Archive of the Volgograd Region], F. 1128, Op. 1, D. 4.

31. Telefonogramma Upravleniya NKVD SSSR po delam o voennoplennykh i internirovannykh nachalniku spetslagerya № 0108 o nemedlennoy peredache spetskontingenta $\mathrm{v}$ postoyannye kadry STZ [A Telephone Message from the Department of the NKVD of the USSR on Prisoners of War and Internees to the Head of Special Camp no. 0108 on the Immediate Transfer of Special Squads to Permanent Personnel of the STZ]. Gosudarstvennyy arkhiv Volgogradskoy oblasti [State Archive of the Volgograd Region], F. 1128, Op. 1, D. 8.

32. Chertoprud S. NKVD-NKGB v gody Velikoy Otechestvennoy Voyny [NKVD-NKGB in the Years of the Great Patriotic War]. Moscow, Yauza Publ.; Eksmo Publ., 2005. 416 p.

33. Shevchenko V.V. Deyatelnost lagerey spetsialnogo naznacheniya NKVD SSSR v 19411946 godakh: dis. ... kand. ist. nauk [Activities of Special Purpose Camps of the NKVD of the USSR in 1941-1946. Cand. hist. sci. diss.]. Volgograd, 2010. 223 p.

\section{Information About the Authors}

Sergey G. Sidorov, Doctor of Sciences (History), Professor, Department of History of Russia, Volgograd State University, Prosp. Universitetsky, 100, 400062 Volgograd, Russian Federation, histrus@volsu.ru,https://orcid.org/0000-0002-1366-5787

Vladimir V. Shevchenko, Candidate of Sciences (History), Academic Secretary of Museum of History of the Old Sarepta, Izobilnaya St., 10, 400026 Volgograd, Russian Federation, v-shevchenko@yandex.ru, https://orcid.org/0000-0002-8353-0204

\section{Информация об авторах}

Сергей Григорьевич Сидоров, доктор исторических наук, профессор, профессор кафедры истории России, Волгоградский государственный университет, просп. Университетский, 100, 400062 г. Волгоград, Российская Федерация, histrus@volsu.ru, https://orcid.org/0000-0002-1366-5787

Владимир Вячеславович Шевченко, кандидат исторических наук, ученый секретарь, Музей-заповедник «Старая Сарепта», ул. Изобильная, 10, 400026 г. Волгоград, Российская Федерация, v-shevchenko@yandex.ru, https://orcid.org/0000-0002-8353-0204 